\title{
CORRELATION OF ULTRASONOGRAPHY FINDINGS OF WALL PATTERN AND DISCONTINUITY OF WALL WITH PER-OPERATIVE FINDING FOR PERFORATION OF APPENDIX
}

\author{
Venugopal Kodumur', Krishna Kumar Rama Krishnan², N. Parthiban ${ }^{3}$
}

${ }_{1}^{1}$ Assistant Professor, Department of Radiology, Aarupadai Veedu Medical College and Hospital, Pondicherry, India. 2 Associate Professor, Department of Radiology, Aarupadai Veedu Medical College and Hospital, Pondicherry, India. ${ }^{3}$ Assistant Professor, Department of Surgery, Aarupadai Veedu Medical College and Hospital, Pondicherry, India.

ABSTRACT
BACKGROUND
Ultrasonography is widely used for diagnosis of appendicitis.[1-4] There have been not much literature for diagnosing perforated
appendicitis by evaluating wall pattern and wall thickness by USG. In this study, we evaluated wall thickness and wall pattern for
diagnosing perforated appendix.
Aims and Objectives- Ultrasonography characterisation of wall pattern in inflamed appendix compared to normal appendix.
Correlation of wall pattern and discontinuity of wall of perforated and non-perforated appendicitis with post-operative findings.

\section{MATERIALS AND METHODS}

Study Type- Observational Diagnostic Study. Study of the role of ultrasonography in characterisation of wall pattern and wall thickness in inflamed appendix in correlation with per-operative findings. Wall pattern of appendix is classified into thickened wall with preservation of or intact wall pattern, diffuse loss of normal wall pattern and focal discontinuity in submucosal layer. Study was conducted in the period, September 2015 to April 2017. 200 patients with positive findings for appendicitis by ultrasonography were selected for this study. Scanning RIF with graded compression technique with Transducers Linear Array 6 $\mathrm{MHz}$ to $11 \mathrm{MHz}$ and curvilinear array 3.0 to $6 \mathrm{MHz}$. Patients are excluded who presented with symptoms related to other organ systems and when ultrasound was not used as an initial evaluation of method. Any patient having excessive bowel gas, in whom visualisation of appendix becomes difficult, is excluded from the study. Ultrasonography findings are correlated only with peroperative finding.

\section{RESULTS}

At surgery $52(26 \%)$ of the 200 patients proved to have perforated appendicitis and 148 patients (76\%) did not have perforated appendicitis. Focal discontinuity and loss of normal wall pattern are common if diameter of appendix is more than $8 \mathrm{~mm}$, though it may present in lesser diameter. When there is only thickened wall with no discontinuity, the specificity to rule out perforation is $100 \%$ with confidence interval of $16 \%$ to $100 \%$. As there is no perforation by USG in this table, sensitivity is $0 \%$. The sensitivity to diagnose perforation in focal discontinuity of submucosal layer is $89 \%$ and specificity is $75 \%$ with accuracy of $76.92 \%$. The sensitivity to diagnose perforation in diffuse loss of wall pattern is $68 \%$ (CI $50 \%$ to $83 \%$ ) and specificity is $80 \%$ (CI- $44 \%$ to $97 \%$ ) with accuracy of $71 \%$ (CI- $55.42 \%$ to $84.28 \%$ ). Sensitivity and accuracy of detecting perforation by USG is highest for focal discontinuity in submucosal layer of appendix. Sensitivity for non-perforated appendicitis is high for intact wall pattern with thickened wall.

\section{CONCLUSION}

Ultrasonography is widely used to diagnose acute appendicitis. Just to diagnose appendicitis may not be adequate for the surgeon to plan the management. Status regarding perforation may be very important for further management. This is the first attempt to find correlation between wall pattern and wall thickness for perforation. Focal discontinuity in submucosal layer of appendix has more sensitivity for perforation. The sensitivity to diagnose perforation by diffuse loss of normal wall pattern is also good, but comparatively less than focal discontinuity in submucosal layer of appendix. Ultrasonography evaluation of wall thickness and wall pattern in appendicitis may be included in routine practice to give ideas for the surgeon for further management of appendicitis.

\section{KEYWORDS}

Acute Appendicitis, Perforation, Wall Pattern, Ultrasonography, Diagnosis.

HOW TO CITE THIS ARTICLE: Kodumur V, Krishnan KKR, Prathiban N. Correlation of ultrasonography findings of wall pattern and discontinuity of wall with per-operative finding for perforation of appendix. J. Evolution Med. Dent. Sci. 2018;7(17):2108-2113, DOI: $10.14260 /$ jemds/2018/472

'Financial or Other Competing Interest': None.

Submission 14-03-2018, Peer Review 08-04-2018,

Acceptance 11-04-2018, Published 23-04-2018.

Corresponding Author:

Dr. Krishna Kumar Rama Krishnan,

\#11, Priyadarshini Street,

Moogambighai Nagar,

Reddiyarpalayam,

Pondicherry-605010, India.

E-mail: drkrishnar1980@gmail.com

DOI: $10.14260 /$ jemds $/ 2018 / 472$

\section{BACKGROUND}

Ultrasonography is widely used for diagnosis of appendicitis.[1-4] There have been not much literature for diagnosing perforated appendicitis by evaluating wall pattern and wall thickness by USG. In this study, we evaluated wall thickness and wall pattern for diagnosing perforated appendix.

\footnotetext{
Aims and Objectives

Ultrasonography characterisation of wall pattern in inflamed appendix. Correlation of wall pattern with per-operative macroscopic findings for perforated appendicitis.
} 


\section{MATERIALS AND METHODS}

\section{Study Type}

Observational Diagnostic Study.

Study of the role of ultrasonography in characterisation of wall pattern in inflamed appendix done with post-operative findings. Wall pattern of appendix is classified into thickened wall with preservation of wall pattern, diffuse loss of normal wall pattern and discontinuity in submucosal layer. Study was conducted in the period, September 2015 to September 2017. Two hundred patients diagnosed as appendicitis by ultrasonography were selected for this study. Exclusion criteria were pregnancy and patients not willing to participate in this study. The ultrasonography procedure and purpose of the study were explained to the patients, and informed consent was obtained from each patient or from a patient's ward. The hospitalised patients underwent Ultrasonography examination for diagnosing appendicitis. Two hundred patients diagnosed as appendicitis by ultrasonography were included in this study. Results of ultrasonography were compared with post-operative finding.

Ultrasonography examinations were done by expert radiologists using 5 to $11-\mathrm{MHz}$ linear array, 3 to $6-\mathrm{MHz}$ curved array, (GE-Voluson S6, Toshiba Nemio XG). Curved array transducers were used in obese patients to allow deeper penetration. Ultrasonography examinations were performed using the graded compression technique described by Puylaert.[5,6] On Ultrasonography, the primary criterion to establish the diagnosis of acute appendicitis was direct visualisation of the inflamed appendix. The classic appearance is a non-compressible blind-ended tubular structure without peristalsis in RIF with maximum diameter of $6 \mathrm{~mm}$ or larger.[1-6] Wall thickness, wall pattern, discontinuity in submucosal layer of appendix and diffuse loss of wall pattern (Gut signature) noted in inflamed appendix. Perforation of appendix was diagnosed with other supportive finding like free fluid, abscess and phlegmon. Findings of ultrasonography were compared with peroperative macroscopic findings for perforation.

\section{Statistical Method}

The sensitivity, specificity, positive predictive value and accuracy with confidence interval for diagnosing perforation by different wall patterns are calculated. Different wall patterns are: 1 . Thickened wall with no discontinuity, 2. Focal discontinuity in submucosal layer, 3. Diffuse loss of normal wall pattern.

\section{Histological Layers of the Appendix}

The mucosa of the appendix has a simple columnar epithelium shaped into straight tubular crypts. There are no villi. The crypts of Lieberkuhn are straight and unbranched. The crypt epithelium also includes stem cells, which replenish the epithelium every few days. The crypts are separated by conspicuous lamina propria, loose connective tissue infiltrated by many white blood cells with capillaries and thin strands of smooth muscle.[7] Lymph nodules (Fig.1B) are standard features of the appendix, but are normally relatively uncommon elsewhere in the lower tract. Lymphoid nodules frequently accumulate in the submucosa, $[8,9]$ disrupt the muscularis mucosae and extend into the mucosa, almost approaching the luminal surface. The muscularis mucosa forms a thin layer (only a few muscle fibres in thickness) beneath the deep ends of the crypts. The submucosa is relatively unspecialised. Muscularis externa of the appendix has the standard layers of inner circular and outer longitudinal smooth muscle, the outer layer of the appendix is a serosa attached to mesoappendix (Arrow in Fig. 1B).

\section{Correlation of Sonographic and Histologic Layers of Appendix}

By USG wall of appendix appears as five layered structure with alternating hyperechoic and hypoechoic layers ${ }^{[10]}$ as shown in Fig. 2 and 3. They are as follows from luminal to outer layer-

- Hyperechoic- interface of superficial mucosa with luminal content.

- Hypoechoic- deep mucosa including muscularis mucosa.

- Hyperechoic- submucosa.

- Hypoechoic- muscularis propria.

- Hyperechoic- serosa.

The normal appendix can be identified by Transabdominal USG. In whom this is possible, the appendix presents as a very small (diameter $<6 \mathrm{~mm}$ ), non-peristaltic, compressible, mobile structure with blind end.

The caecum, terminal ileum, iliac vessels and iliopsoas muscle act as additional landmarks to detect the appendix. All five layers may not be visualised by USG.

\section{Ultrasonography Appearance of Wall in Appendicitis}

- Wall of appendix is thickened in appendicitis.

- Gut signature may or may not be present in appendicitis.

- Wall thickening with intact gut signature (Fig. 4).

- Diffuse loss of gut signature (Fig. 5).

- Focal discontinuity in submucosal layer (Fig. 6).

\section{Age and Sex Distribution}

The age of the patients involved in study ranges from first decade to sixth decade. Acute appendicitis is more common in 20 - 40 years' age group. There is no sex preponderance.

\section{RESULTS}

At surgery, $52(26 \%)$ of the 200 patients proved to have perforated appendicitis and 148 patients (76\%) did not have perforated appendicitis.

\section{Statistical Data}

The Ultrasonography results for the patients who underwent surgery are listed in Table 1, 2, 3 and 4.

\section{Analysis of Table 1}

Focal discontinuity and loss of normal wall pattern are common if diameter of appendix is more than $8 \mathrm{~mm}$, though it may present in lesser diameter.

\section{Analysis of Table 2}

Correlation of Ultrasonography with thickened wall with no discontinuity and surgery findings for perforation. Out of 132 patients with preservation of wall pattern with thickened wall by ultrasonography shows 130 (99\%) patients with no perforation in surgery and $2(1 \%)$ patients show perforation on surgery. 
When there is only thickening of wall with preservation of wall pattern and no focal discontinuity or loss of normal wall pattern, then the chance for perforation is very rare. Only 2 out of 132 patients had perforation. Incidence of 1.5 per hundred findings. When there is only thickened wall with no discontinuity, the specificity to rule out perforation is $100 \%$ with confidence interval of $16 \%$ to $100 \%$. As there is no perforation by USG in this table, sensitivity is $0 \%$.

\section{Analysis of Table-3}

Correlation of Ultrasonography with focal discontinuity in submucosal layer and surgery findings for perforation. Out of 26 patients with focal discontinuity in submucosal layer by ultrasonography shows 18 (69\%) patients with perforation in surgery. $8(31 \%)$ patients show no perforation on surgery. The sensitivity to diagnose perforation is $89 \%$ (CI $65 \%$ to $98 \%$ ) and specificity is $75 \%$ (CI- $35 \%$ to $98 \%$ ). Positive predictive value to diagnose perforation is $89 \%$ (CI- $70 \%$ to $96 \%$ ) and negative predictive value is $75 \%$ (CI- $43 \%$ to $92 \%$ ). Accuracy $76.92 \%$ (CI- $56.35 \%$ to $91.03 \%$ ).

\section{Analysis of Table-4}

Correlation of Ultrasonography with diffuse loss of normal wall pattern and surgery findings for perforation. Out of 42 patients with but diffuse loss of normal wall pattern by ultrasonography shows $32(76 \%)$ patients with perforation in surgery. $10(24 \%)$ patients show no perforation on surgery. The sensitivity to diagnose perforation is $68 \%$ (CI $50 \%$ to $83 \%$ ) and specificity is $80 \%$ (CI- $44 \%$ to $97 \%$ ). Positive predictive value to diagnose perforation is $91 \%$ (CI$75 \%$ to $97 \%$ ) and negative predictive value is $44 \%$ (CI- $30 \%$ to $60 \%$ ). Accuracy $71 \%$ (CI- $55.42 \%$ to $84.28 \%$ ).

Sensitivity and accuracy of detecting perforation by USG is highest for focal discontinuity in submucosal layer of appendix. Sensitivity for non-perforated appendicitis is high for intact wall pattern with thickened wall.

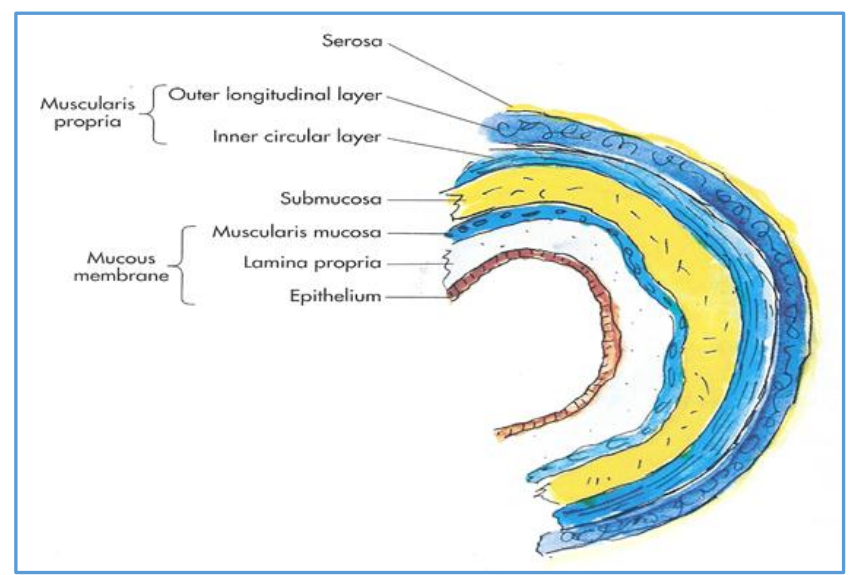

Figure 1A. Schematic Depiction of Histological Layer of Intestine

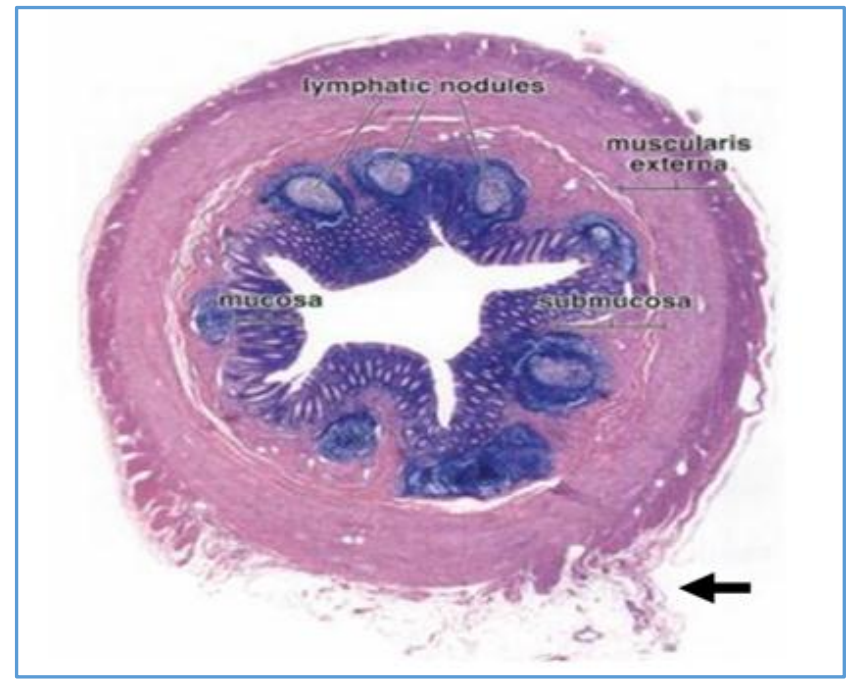

Figure 1B. Histological Layers of Appendix with Parts Marked on diagram, Appendix is covered with Serosa continuous with that of Mesoappendix seen in Lower End of Diagram (Arrow)

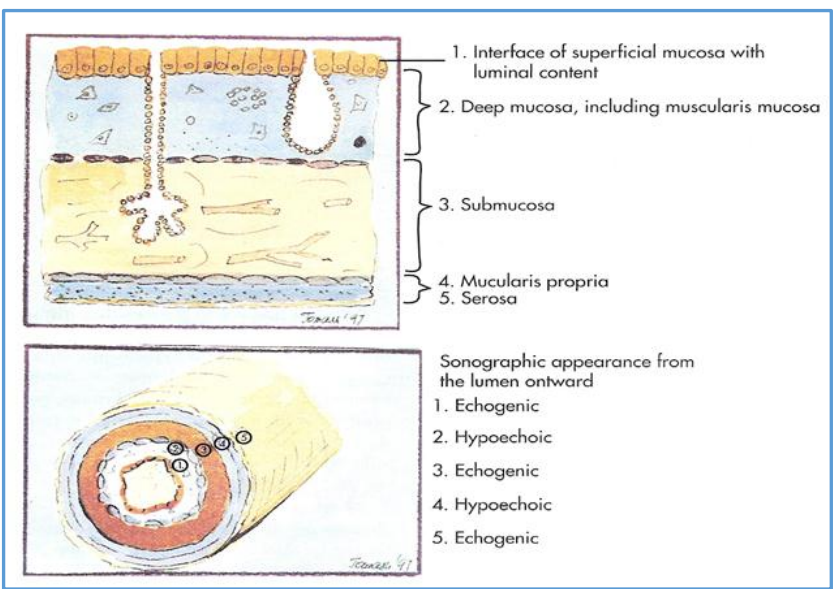

Figure 2. Schematic representation of Bowel Layers. Compare with Figure 3, which shows Normal Appendix in a Patient with Ascites

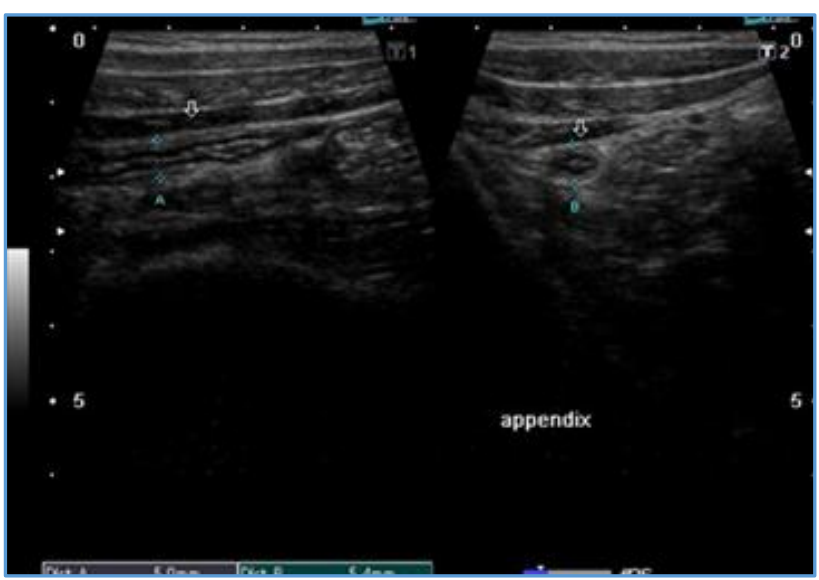

Figure 3. Longitudinal and Transverse View of Normal Appendix (between calibers) which shows all Five Layers Clearly. Diameter of Appendix is $5.4 \mathrm{~mm}$ 


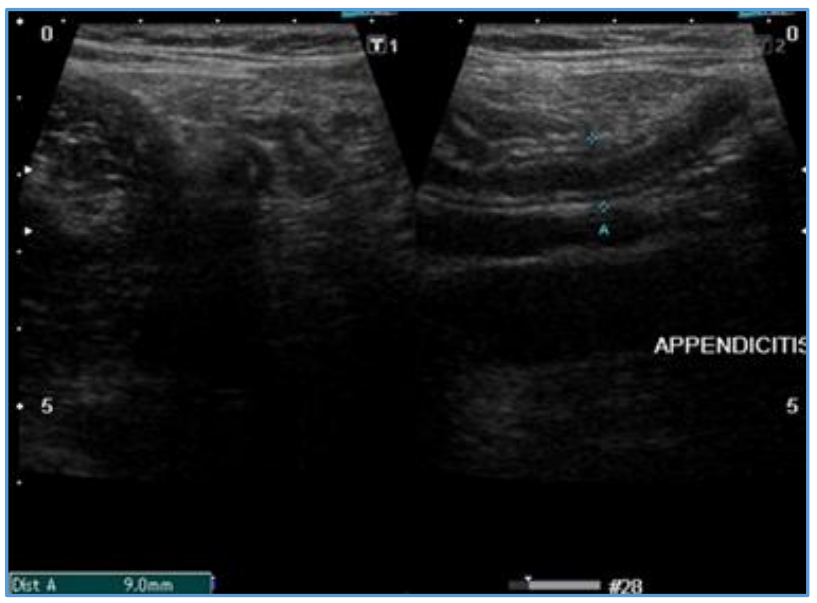

Figure 4. Short and Long Axis View of Inflamed Appendix (between calibers) with Intact Gut Signature

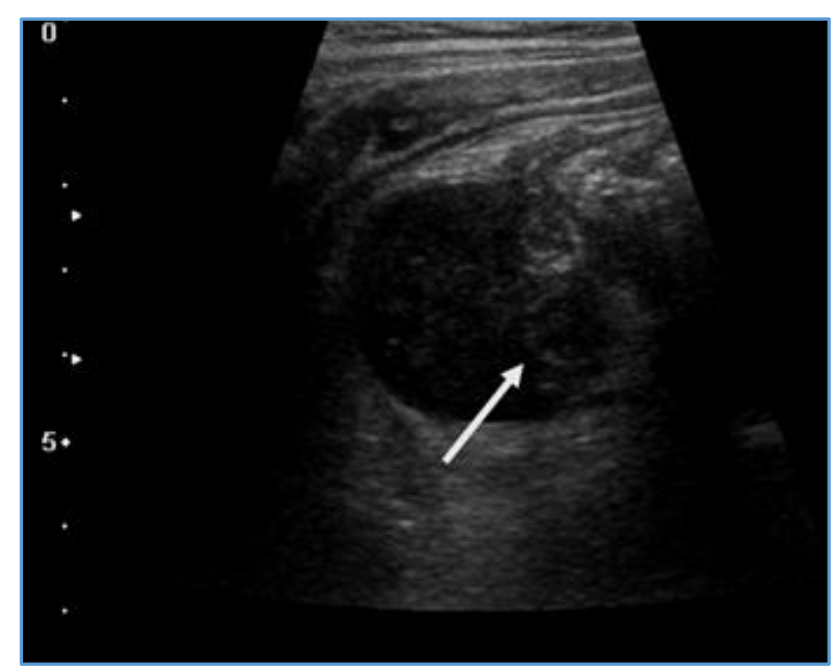

Figure 5. Short Axis View of Inflamed Appendix with Adjacent Abscess. Focal Discontinuity in Submucosal Layer is Well Seen

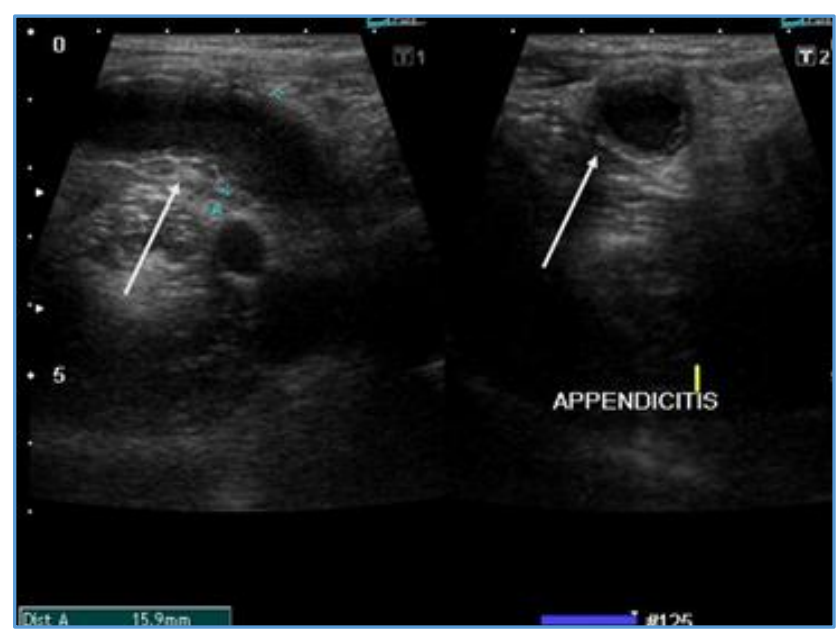

Figure 6. Short and Long Axis View of Inflamed Appendix with diffuse Loss of Wall Pattern

\begin{tabular}{|c|c|c|c|c|}
\hline $\begin{array}{c}\text { Diameter } \\
\text { of } \\
\text { Appendix }\end{array}$ & $\begin{array}{c}\text { Diffuse } \\
\text { Loss of } \\
\text { Normal } \\
\text { Wall } \\
\text { Pattern }\end{array}$ & $\begin{array}{c}\text { Focal } \\
\text { Discontinuity } \\
\text { in Submucosal } \\
\text { Layer }\end{array}$ & $\begin{array}{c}\text { Thickened } \\
\text { Wall with No } \\
\text { Discontinuity }\end{array}$ & Total \\
\hline <6 mm & - & - & - & - \\
\hline 6 to $7 \mathrm{~mm}$ & - & - & 61 & 61 \\
\hline $\begin{array}{c}7.1 \text { to } 8 \\
\mathrm{~mm}\end{array}$ & 3 & 2 & 37 & 42 \\
\hline $\begin{array}{c}8.1 \text { to } 9 \\
\text { mm }\end{array}$ & 9 & 5 & 18 & 32 \\
\hline $\begin{array}{c}9.1 \text { to } 10 \\
\text { mm }\end{array}$ & 14 & 8 & 12 & 34 \\
\hline$>10 \mathrm{~mm}$ & 16 & 11 & 4 & 31 \\
\hline \multicolumn{5}{|c|}{ Table 1. Distribution of Wall Pattern according to } \\
Diameter of Inflamed Appendix \\
\hline
\end{tabular}

\begin{tabular}{|c|c|c|c|}
\hline \multirow{2}{*}{$\begin{array}{l}\text { Surgery } \\
\text { Findings }\end{array}$} & \multicolumn{2}{|c|}{$\begin{array}{l}\text { Ultrasonography with } \\
\text { Thickened Wall with No } \\
\text { Discontinuity }\end{array}$} & \multirow{2}{*}{$\begin{array}{c}\text { No. of } \\
\text { Patients }\end{array}$} \\
\hline & $\begin{array}{c}\text { No } \\
\text { Perforation } \\
\end{array}$ & $\begin{array}{c}\text { Perforation } \\
\text { Present }\end{array}$ & \\
\hline No perforation & 130 & 0 & 130 \\
\hline $\begin{array}{c}\text { Perforation } \\
\text { present }\end{array}$ & 2 & 0 & 2 \\
\hline Total & 132 & $\mathbf{0}$ & 132 \\
\hline \multicolumn{4}{|c|}{$\begin{array}{c}\text { Table 2. Correlation of Ultrasonography with Thickened } \\
\text { Wall with No Discontinuity and Surgery Findings for } \\
\text { Perforation }\end{array}$} \\
\hline
\end{tabular}

\begin{tabular}{|c|c|c|c|}
\hline \multirow{2}{*}{$\begin{array}{c}\text { Surgery } \\
\text { Findings }\end{array}$} & $\begin{array}{c}\text { Ultrasonography with Focal } \\
\text { Discontinuity in Submucosal } \\
\text { Layer }\end{array}$ & \multirow{2}{*}{$\begin{array}{c}\text { No. of } \\
\text { Patients }\end{array}$} \\
\cline { 2 - 3 } & $\begin{array}{c}\text { No } \\
\text { Perforation }\end{array}$ & $\begin{array}{c}\text { Perforation } \\
\text { Present }\end{array}$ & \\
\hline No perforation & 6 & 2 & 8 \\
\hline $\begin{array}{c}\text { Perforation } \\
\text { present }\end{array}$ & 2 & 16 & 18 \\
\hline Total & $\mathbf{8}$ & $\mathbf{1 8}$ & $\mathbf{2 6}$ \\
\hline $\begin{array}{c}\text { Table 3. Correlation of Ultrasonography with Focal } \\
\text { Discontinuity in Submucosal Layer and Surgery Findings } \\
\text { for Perforation }\end{array}$ \\
\hline \multicolumn{4}{|c}{} \\
\hline
\end{tabular}

\begin{tabular}{|c|c|c|c|}
\hline \multirow{2}{*}{$\begin{array}{l}\text { Surgery } \\
\text { Findings }\end{array}$} & \multicolumn{2}{|c|}{\begin{tabular}{|c|} 
Ultrasonography with Diffuse \\
Loss of Normal Wall Pattern
\end{tabular}} & \multirow{2}{*}{$\begin{array}{c}\text { No. of } \\
\text { Patients }\end{array}$} \\
\hline & $\begin{array}{c}\text { No } \\
\text { Perforation }\end{array}$ & $\begin{array}{c}\text { Perforation } \\
\text { Present }\end{array}$ & \\
\hline No perforation & 8 & 2 & 10 \\
\hline $\begin{array}{c}\text { Perforation } \\
\text { present }\end{array}$ & 10 & 22 & 32 \\
\hline Total & 18 & 24 & 42 \\
\hline \multicolumn{4}{|c|}{$\begin{array}{c}\text { Table 4. Correlation of Ultrasonography with diffuse Loss } \\
\text { of Normal Wall Pattern and Surgery Findings for } \\
\text { Perforation }\end{array}$} \\
\hline
\end{tabular}


RESULTS

\begin{tabular}{|c|c|c|c|}
\hline Statistic & Formula & Value & $95 \% \mathrm{CI}$ \\
\hline \multirow{2}{*}{ Sensitivity } & $a$ & 88.89 & $65.29 \%$ to \\
\hline & $\overline{a+b}$ & $\%$ & $98.62 \%$ \\
\hline \multirow{2}{*}{ Specificity } & $d$ & 75.00 & $34.91 \%$ \\
\hline & $\overline{c+d}$ & $\%$ & to $96.81 \%$ \\
\hline \multirow{2}{*}{$\begin{array}{c}\text { Positive } \\
\text { Likelihood } \\
\text { Ratio }\end{array}$} & Sensitivity & \multirow{2}{*}{3.56} & \multirow{2}{*}{$\begin{array}{c}1.06 \text { to } \\
11.94\end{array}$} \\
\hline & $1-$ Specificity & & \\
\hline \multirow{2}{*}{$\begin{array}{c}\text { Negative } \\
\text { Likelihood } \\
\text { Ratio }\end{array}$} & $1-$ Sensitivity & \multirow{2}{*}{0.15} & \multirow{2}{*}{$\begin{array}{c}0.04 \text { to } \\
0.58\end{array}$} \\
\hline & Specificity & & \\
\hline \multirow{2}{*}{$\begin{array}{c}\text { Disease } \\
\text { Prevalence }\end{array}$} & $a+b$ & 69.23 & \multirow{2}{*}{$\begin{array}{c}48.21 \% \text { to } \\
85.67 \%\end{array}$} \\
\hline & $a+b+c+d$ & $\%(*)$ & \\
\hline \multirow{2}{*}{$\begin{array}{c}\text { Positive } \\
\text { Predictive } \\
\text { Value }\end{array}$} & $a$ & 88.89 & \multirow{2}{*}{$\begin{array}{c}70.44 \% \text { to } \\
96.41 \%\end{array}$} \\
\hline & $a+c$ & $\%(*)$ & \\
\hline \multirow{2}{*}{$\begin{array}{c}\text { Negative } \\
\text { Predictive } \\
\text { Value }\end{array}$} & $\bar{d}$ & \multirow{2}{*}{$\begin{array}{c}75.00 \% \\
\left(^{*}\right)\end{array}$} & \multirow{2}{*}{$\begin{array}{c}43.34 \% \text { to } \\
92.17 \%\end{array}$} \\
\hline & $\overline{b+d}$ & & \\
\hline \multirow{2}{*}{ Accuracy } & $a+d$ & \multirow{2}{*}{$\begin{array}{l}84.62 \\
\%\left(^{*}\right)\end{array}$} & \multirow{2}{*}{$\begin{array}{c}65.13 \% \text { tc } \\
95.64 \%\end{array}$} \\
\hline & $\overline{a+b+c+d}$ & & \\
\hline
\end{tabular}

\section{DISCUSSION}

We evaluated wall thickness and wall pattern for perforation of appendix. Focal discontinuity and diffuse loss of normal wall pattern are common if diameter of appendix is more than $8 \mathrm{~mm}$, seen in 97 patients out of 200 (48\%). Chance of perforation is high when the diameter is more than $8 \mathrm{~mm}$, although perforation seen in diameter less than 8 but less frequently. Focal discontinuity in submucosal layer of appendix has more sensitivity than diffuse loss of normal wall pattern. Sensitivity for non-perforated appendicitis is high for intact wall pattern with thickened wall.

Ultrasonography technique and usage of ultrasonography for diagnosing appendicitis is evolved in recent times. Many studies support accuracy of USG is equivalent to CT in recent times.[11] Graded compression technique is increasingly used in establishing the diagnosis of acute appendicitis.[12-14]

Wall pattern and wall thickness are better assessed with ultrasonography because of soft tissue contrast better than CT, which adds to the diagnostic efficiency of ultrasonography in acute appendicitis.

A guidance by ultrasonography for perforation may be very important to plan the surgery.[15-20] Some may prefer to manage conservatively and then go for interval appendectomy.[15,16] For them the ultrasonographic finding regarding the statues of perforation may be very important.

Layered wall pattern is better seen in USG. Loss of triple layer wall pattern by ultrasonography in acute appendicitis may denote perforation, gangrene or severe inflammation with possible adhesion.

Disadvantage of graded compression ultrasonography is operator-dependent and requires expertise. Obese patients and patients with a retrocaecal appendix or with severe abdominal pain are difficult to examine using ultrasonography.[2]

\section{CONCLUSION}

Ultrasonography is widely used to diagnose acute appendicitis. Just to diagnose appendicitis may not be adequate for the surgeon to plan the management. Status regarding perforation may be very important for further management. This is the first attempt to find correlation between wall pattern and wall thickness for perforation. Focal discontinuity in submucosal layer of appendix has more sensitivity for perforation.[21] The sensitivity to diagnose perforation by diffuse loss of normal wall pattern is also good, but comparatively less than focal discontinuity in submucosal layer of appendix. Ultrasonography evaluation of wall thickness and wall pattern in appendicitis may be included in routine practice to give ideas for the surgeon for further management of appendicitis.

\section{REFERENCES}

[1] Rioux M. Sonographic detection of the normal and abnormal appendix. Am J Roentgenol 1992;158(4):773-8.

[2] Simonovsky V. Sonographic detection of normal and abnormal appendix. Clin Radiol 1999;54(8):533-9.

[3] Eldar S, Nash E, Sabo E, et al. Delay of surgery in acute appendicitis. Am J Surg 1997;173(3):194-8.

[4] Abu-Yousef MM, Bleicher JJ, Maher JW, et al. Highresolution sonography of acute appendicitis. AJR Am J Roentgenol 1987;149(1):53-8.

[5] Puylaert JB, Rutgers PH, Lalisang RI, et al. A prospective study of ultrasonography in the diagnosis of appendicitis. N Engl J Med 1987;317(11):666-9.

[6] Puylaert JB. Acute appendicitis: US evaluation using graded compression. Radiology 1986;158(2):355-60.

[7] Emre A, Akbulut S, Bozdag Z, et al. Routine histopathologic examination of appendectomy specimens: retrospective analysis of 1255 patients. Int Surg 2013;98(4):354-62.

[8] Spencer J, Finn T, Isaacson PG. Gut associated lymphoid tissue: a morphological and immunocytochemical study of the human appendix. Gut 1985;26(7):672-9.

[9] Kooij IA, Sahami S, Meijer SL, et al. The immunology of the vermiform appendix: a review of the literature. Clinical Experimental Immunology 2016;186(1):1-9. doi: 10.1111/cei.12821

[10] Park NH, Oh HE, Park HJ, et al. Ultrasonography of normal and abnormal appendix in children. World J Radiol 2011;3(4):85-91.

[11] Pinto F, Pinto A, Russo A, et al. Accuracy of ultrasonography in the diagnosis of acute appendicitis in adult patients: review of the literature. Critical Ultrasound Journal 2013;5(Suppl 1):S2.

[12] Stroman DL, Bayouth CV, Kuhn JA, et al. The role of computed tomography in the diagnosis of acute appendicitis. Am J Surg 1999;178(6):485-9.

[13] Abu-Yousef MM, Bleicher JJ, Maher JW, et al. Highresolution Ultrasonography of acute appendicitis. AJR 1987;149(1):53-8.

[14] Franke C, Bohner H, Yang Q, et al. Ultrasonography for diagnosis of acute appendicitis: results of a prospective multicenter trial. Acute Abdominal Pain Study Group. World J Surg 1999;23(2):141-6. 
[15] Van Randen A, Laméris W, van Es HW, et al. A comparison of the accuracy of ultrasound and computed tomography in common diagnoses causing acute abdominal pain. Eur Radiol 2011;21(7):1535-45.

[16] Ein SH, Langer JC, Daneman A. Nonoperative management of pediatric ruptured appendix with inflammatory mass or abscess: presence of an appendicolith predicts recurrent appendicitis. J Pediatr Surg 2005;40(10):1612-5.

[17] Zhang HL, Bai YZ, Zhou X. Nonoperative management of appendiceal phlegmon or abscess with an appendicolith in children. J Gastrointest Surg 2013;17(4):766-70.

[18] Kogut KA, Blakely ML, Schropp KP, et al. The association of elevated percent bands on admission with failure and complications of interval appendectomy. J Pediatr Surg 2001;36(1):165-8.
[19] St Peter SD, Aguayo P, Fraser JD, et al. Initial laparoscopic appendectomy versus initial nonoperative management and interval appendectomy for perforated appendicitis with abscess: a prospective, randomized trial. J Pediatr Surg 2010;45(1):236-40.

[20] Iqbal CW, Knott EM, Mortellaro VE, et al. Interval appendectomy after perforated appendicitis: what are the operative risks and luminal patency rates? J Surg Res 2012;177(1):127-30.

[21] Blumfield E, Nayak G, Srinivasan R, et al. Ultrasound for differentiation between perforated and nonperforated appendicitis in pediatric patients. AJR Am J Roentgenol 2013;200(5):957-62. doi: 10.2214/AJR.12.9801 